\title{
Thoughts on Strengthening Safety of Rural Water Supply in the New Era- Taking Binxian County, Shaanxi Province as an Example
}

\author{
Ji Liang ${ }^{1, *}$, Haitao Zhang ${ }^{2}$, Jinbo Qin ${ }^{1}$ \\ ${ }^{1}$ Huazhong University of Science and Technology, Luo Yu Road of Hongshan District No. 1037, Wuhan 430074, China \\ ${ }^{2}$ Development Research Center of the Ministry of Water Resources of P.R.China, Haidian District Yuyuantan South Road No. 3, Beijing \\ 100038, China.
}

\begin{abstract}
At present, our country has entered a new era. The report of the 19th National Congress of CPC pointed out that we must always put the top priority of the Party's work on solving the problem of agriculture, rural areas and farmers. The safety of rural water supply safety is the direct and realistic interest-related problem that the rural masses most concern. In the new era, we should further strengthen the safety work of rural water supply, gradually promote the integration of urban and rural water supply, and effectively solve the increasingly serious safety-related demand of water supply of villagers and the contradiction caused by uneven and insufficient development of urban and rural water supply. Binxian County is located in the water shortage area in the west of China. The management model of "urbanizing rural water supply" that the county explored to establish has effectively solved the problem about the construction, operation and maintenance of rural water supply project. It accords with the development idea of rural water supply in the new era, and its successful experience can be duplicated and popularized in Shaanxi Province and even in the whole country.
\end{abstract}

\section{Major Problems related to Operation and Maintenance of Rural Water Supply Projects}

Compared with urban water supply, there are still some problems in rural water supply, such as small water supply scale, low guarantee rate of water supply, incomplete water purification facilities, high leakage rate, low rural household admission rate and low quality rate, and low level of information technology utilization and professional management.

\subsection{Low Construction Standard of Some Water Supply Project}

The rural water supply projects are small in scale, and have many supply points, and the supply area is vast and the supply volume is large. By the end of 2015, China had 1 million rural centralized water supply projects and over $90 \%$ of them were small-scale single-village water supply projects, accounting for more than $40 \%$ of the water supply population. Some of the rural water supply engineering facilities and water supply pipelines were built according to low construction standards, especially for the about 300000 centralized water supply projects built before 2004. The water intake and supply projects, water purification facilities and pipe network are aged seriously, so the water supply projects are poorly reliable and the leakage rate of the pipe network is more than
$20 \%$.

\subsection{Hidden Safety Risk on Water Quality}

Some water supply projects lack the necessary water treatment facilities and equipments; some water supply projects selected improper treatment processes; many rural water supply projects can only rely on unqualified water supply sources, such as high fluorine water, high arsenic water, high iron and manganese water, bitter salt water, and even polluted water. The guarantee rate of drinking water and the sanitary indexes of water quality are low, and there are some serious hidden risks about the safety of water quality. In addition, there are no drainage facilities and sewage treatment systems in some villages. The wastewater is discharged randomly, and the rainwater and sewage flows anywhere. Not only the surface water and the shallow groundwater source are polluted, but the deep groundwater is also in face of the risk of pollution, and the water quality has the potential safety hazard.

\subsection{Low Management and Service Level of Rural Water Supply}

The operation and maintenance of many rural water supply projects is carried out only by employed or designated temporary workers, who are generally old and lack professional operation and maintenance knowledge

* Corresponding author: E-Mail(Liang): larkwater1@163.com;Tel.:+86 13297009229 
of water supply engineering; they can hardly be arranged at the fixed post. The lower salary level cannot attract young people and professional technicians, resulting the low management and service level of water supply in the rural areas.

\subsection{Operation and Maintenance Funds of Water Supply Project cannot be Guaranteed}

The formation mechanism of water prices in some rural areas is unreasonable, and the water price is lower than the operating cost and the actual water fee collection rate is low. In some rural areas, the water supply meter reading system is not perfect, and some rural residents do not understand the water price policy, and do not want to pay water fees, so the water meter reading and water fee collection are difficult. In addition, the lack of maintenance and maintenance funds results in the shortage of maintenance costs of rural water supply projects, so the water supply project cannot continue to exert the healthy and sustained effect and this affects the safety of rural drinking water.

\section{Management Mode of "Urbanizing Rural Water Supply" in Binxian County}

Binxian County is a mountainous county under the jurisdiction of Xianyang City in Shaanxi Province. It is located in the gully region in the west of Weibei dry highland. In recent years, Binxian County gradually explored a new way of "urbanizing rural water supply" featuring with "strict control of quality, meticulous maintenance, unified management and standardized operation" according to the practical work of rural water supply management. This helped the rural water supply management of the whole country become more institutionalized, standardized and scientific, and greatly promoted the safety level of rural water supply in Binxian County.

\subsection{Strictly Control Quality to Ensure Construction of Water Supply Projects to Meet Standard}

When Binxian County was constructing rural water supply project, it mainly took three measures to ensure the construction of water supply project to meet the standard: First, determined clear goal of project construction; put forward project quality requirements, and adopted the responsibility system of leadership and the life-long responsibility system of project quality. Second, in the project bidding, selected qualified, experienced and credible construction company, and control the strict construction procedures in every step to guarantee the project quality. Third, Binxian County Rural Water Supply Management General Station (hereinafter referred to as "the water supply station") arranged engineering technicians to stay on the construction site for the new rural water supply project, to provide technical guidance and the quality supervision, to ensure the quality to meet the standard. During the "12th Five-Year" period, Binxian County built 185 people-drinking water projects, and all of them were tested and assessed by the quality inspection department of the higher water conservancy projects as qualified projects, of which $20 \%$ of the water supply projects were evaluated as excellent projects.

\subsection{Careful Maintenance to Ensure Perfect Operation of Water Supply Projects.}

Binxian County has regarded perfect daily maintenance of rural water supply facilities as a key link to ensure the safety of rural water supply. 1) Regular inspection and maintenance. Binxian County clearly required the water supply management stations, waterworks and grass-roots water plumbers of all towns to check all the water supply network equipments and structures in the area regularly every month, and remove failure in time; at the same time, it arranged on-duty reporters in all the villages, to ensure minor failures of the water supply facilities to be repaired immediately, overhaul to be completed no later than the next day, and the user's repair request to be satisfied anytime and anywhere. 2) Serious pursuit of accountability. Binxian County has formulated the relevant regulations and punishment measures for the maintenance and management of the rural water supply facilities. If the leakage of the water supply pipe network equipment is not repaired in time and the fault is not eliminated in time, the responsible plumbers will be fined with penalty of 10-100 Yuan according to the different circumstances, and this effectively standardized and promoted the water supply management stations and the waterworks to perfectly perform their duties in maintenance and management of routine water supply pipe network and equipments and facilities in time. 3) Perfect financial security. Binxian County has formulated the water supply facilities overhaul reserve fund system. According to the water supply capacity of the basic water supply management stations and waterworks, 0.20 Yuan per cubic meter of water was collected as overhaul reserve fund, and was uniformly deposited in the special bank account of water supply general station. The fund is specially management and is to be used only for overhaul purpose. In recent years, the intactness and safety rates of rural water supply equipments and facilities in Binxian County had been maintained at over $95 \%$.

\subsection{Unified Management to Improve Capacity of Water Supply Management}

On the basis of the actual situation of rural water supply and utilization, Binxian County innovated on the management mechanism and strengthened the unified management. 1) Unified management organization. In July 1991, Binxian County set up a water supply general station, which is under the jurisdiction of the Binxian County Water Conservancy Bureau. In the same year, all towns established a town water supply management stations. In 2000, Binxian County Water Conservancy Bureau integrated the personnel, finance and operation management of water supply management stations and 
82 waterworks in 8 towns in the county into the unified management under the water supply general station, and properly handled the pension plan for the employees. 2) Unified management method. In 2013, Binxian County formulated the "Binxian County Rural Water Supply Management Measures", and clearly stipulated the responsibilities and tasks of water supply stations, town water supply management stations and water works. According to the management measures of rural water supply in Binxian County, the township water supply management stations had formulated the "Town Water Supply Management Measures" in line with their respective management practices. 3) Water supply from the unified water pipeline network. During the "12th Five-Year", Binxian County broke the original scattered water supply pattern of one village and one tower, actively promoted the water supply facilities of the towns to be linked together, to uniformly supply water; it uniformly integrated the water sources, towns and cross-town water supply into the water supply project plan and put it into practice, effectively improving the safety level of water supply in rural areas. 4) Unified verified water price. In view of the prominent problems in the early rural water supply network of Binxian County, such as large amount of maintenance work, high cost of water supply, loss of water supply management stations and water works, and different water supply prices in each town, Binxian County has fully verified the price of rural water supply in the whole county, effectively reversed the adverse situations that existed in the water supply of the country, such as: different water supply price, long-term loss of town level water supply stations and water works.

\subsection{Standardize Operation and Improve Water Supply Service Level}

Binxian County took many measures to regulate the operation and management of rural water supply. 1) Creating rules and regulations. It had created and implemented "one file, two accounts, three cards" and "four unification" management system for rural water supply, that is, making user files, waterworks accounts and user accounts; making user payment cards, notice cards of meter reading personnel and user acknowledgement card; unifying water supply management, water price, bill of charge and charging time, and standardizing the management of water supply at the grass-roots level; effectively eliminating "favorable price of internal personnel" and "special offer to relatives of management personnel". 2) Linking computers for uniform operation and management. Binxian County set up water fee charge hall in the water supply management station of each town, equipped with computer, printer and other office facilities, connected with the computer of the water supply general station, so that the two level water supply management stations of the county has realized the information network management, and the collection of water charge will issue computer-printed documents. 3) Strengthening the audit. Binxian County strictly manages the financial revenue and expenditure for rural water supply and strictly collects the water fees, strictly creates and reports the financial statements, and ensures the accounts to be cleaned every day and announced every month, to let the accounts match the funds, the accounts match the articles and the invoices to be qualified; it ensures that the accounts are true, complete and reliable. In accordance with the management methods of "two lines of revenue and expenditure", the county carries out strict internal audit of the finance, and seriously punishes the persons who violate the financial management and the financial discipline according to the relevant regulations. 4) Strict assessment. At the beginning of each year, "Target Responsibility Agreement" or "Water Supply Contract" will be signed between Binxian County Water Conservancy Bureau and the water supply station, the water supply station and the water supply management station of each town, the town level water supply management stations and the waterworks. The water supply task and the economic indicators will be assigned to specific persons, and the rewards and punishments will be strictly carried out every month according to the assessment of each person.

\section{Countermeasures and Suggestions}

It is suggested to promote the mode of "Urbanizing Rural Water Supply" in Binxian County and to further strengthen and improve the work of water supply in rural areas. The construction and management of rural water supply and drainage projects should be carried out according to the principle of large scale of centralized water supply, decentralized water supply standardization, the integration of urban and rural water supply, the integration of water supply and drainage and the long-term operation and management, to ensure the safety of rural water supply, so as to provide a good drinking water safety guarantee for achieving the rural revitalization strategies of the 19th National Congress of CPC and comprehensively building a well-off society.

\subsection{Overall Planning to Build an Integrated Pattern of Urban and Rural Water Supply}

The rural water supply should be coordinated with the urbanization construction and the new rural construction. According to the overall planning of urban and rural areas, the current water supply demand and the trend of the long-term centralized water supply should be fully considered, to establish a suitable rural water supply development model that let urban area to drive the town area and let town area to drive the rural area. We should do a good job in planning and layout of rural water supply projects, make full use of existing water and urban and rural water supply facilities, and build a large-scale city-town integrated and town-village integrated water supply pattern through the reconstruction and expansion of water sources and water works, extension and renovation of pipe network and other engineering construction. 


\subsection{Take Measures to Ensure the Safety of Water Supply in Rural Areas}

Through various effective measures, we should strive to achieve equalization of public water supply services, to ensure that farmers drink the same standard drinking water as urban residents. First, we should promote the classification and delineation of water source protective zones or protective range. For the centralized drinking water source of more than one thousand people, the water source protective area should be scientifically coded and the water source should be delimited; the protection range should be defined for the drinking water source for the water supply of less than 1000 people. Second, we should equip with perfect water treatment and disinfection facilities. For the centralized water supply project, the water treatment and disinfection facilities should be perfected, and the necessary water quality testing instruments should be equipped. For the scattered water supply to farmers who do not have the centralized water supply conditions, the water supply facility should be equipped with small purifying filters and disinfection facilities and the necessary household water purification equipment according to the water quality. Third, we should improve the water quality monitoring and detection ability. We should strengthen the construction of water quality inspection center at the county level; we should set up water quality laboratory for the centralized water supply works of "thousand tons capacity and over 10 thousands consumers", and carry out training to technical personnel to improve the equipment level and detection ability of water quality inspection facilities in the water supply project; the water quality monitoring of the scattered water supply project should be fully covered. Fourth, we should explore to establish an integrated management mode of water supply and drainage in line with the rural characteristics. We should refer to the experience of integrated development of urban water supply and drainage, speed up the construction of drainage facilities, and explore to establish the construction mode and operation management mode of the integrated rural water supply and drainage facilities.

\subsection{Standardize Operation to Improve the Professional Management Service Level of Rural Water Supply.}

We should establish standardized rural water supply management and operation mechanism that meets the requirements of the new era, accords with the characteristics of the rural water supply projects, has specific management body and consistent rights, responsibilities and interests, to improve the professional service level of rural water supply. First, we should improve the management team. In view of the status of too many aged management personnel and the weak technical force at the grass-roots level of rural water supply project, we should actively explore and implement the employment system that "can attract talents, keep talents and let talents perform well", to attract more young people with professional knowledge to enter the frontline posts of rural water supply to provide water supply service. Second, we should improve the scientific and technological level of water supply service. We should promote the application of new materials, new process and new technology, and explore the pilot work of automatic water supply, automatic monitoring, automatic control, automatic measurement and remote charge, so as to improve the scientific and technological level of the rural water supply service. Third, we should strengthen technical training. We should organize to compile the technical manuals for different types of rural water supply projects, and to strengthen the training to rural water supply management and technical personnel by holding training classes and TV media publicity, and implement the system of requiring workers to hold certificates before working in posts.

\subsection{Multiple Operations to Improve the Level of Capital Guarantee}

We should raise funds for construction and maintenance of rural water supply projects through various channels together with the work of rural drinking water project construction, comprehensive improvement of rural environment and new rural construction. We should adjust the structure of financial investment and the ways of investment, such as: establishing the government guidance funds, the appropriate transfer of profits of the equity income of the government investment, financial discount, the investment subsidy and the arrangement of the early-stage funds, so as to give full play to the guiding role of the public finance and encourage the domestic and foreign enterprises, the social and the folk funds to invest in the rural water supply projects and promote the socialized operation of the construction and maintenance funds of water supply projects in the rural areas. At the same time, in accordance with the "Rural Drinking Water Safety Engineering Construction and Management Measures" and other regulations, we should strengthen the management of funds, implement the favorable policies for electricity and land use and tax incentives, to promote the construction of rural water supply institutions, environmental monitoring institutions and maintenance and maintenance funds, and ensure the rural water supply projects to safely and stably exert effectiveness on the long-term basis.

\subsection{Taking Preventive Measures to Improve Emergency Water Supply Capacity in Rural Areas}

We should strengthen the construction of automatic monitoring capability of centralized water supply projects, and improve the online monitoring and safety warning functions for key indicators, such as water quality, water volume and water pressure. We should take the administrative area of the county or town as the basic unit, set up emergency command organization and perfect the drought and water pollution and other disasters preventive scheme and emergency water supply 
plan, to reserve the emergency water supply materials and equipments, and provide emergency repair tools, and rely on rural water supply management organizations, drought resisting service team, the maintenance personnel of large-scale waterworks and other personnel to build a professional team, to ensure that we can respond to and deal with the emergency water supply accidents in rural areas in time.

\section{References}

1. Yang JF, Li B (2017) Discussion on the status quo and development of rural water supply in China. China Water Resources (7):23-25(in Chinese)

2. Zhang MJ, Wang YT, Zhao YQ, Sun FH, Tian ZG (2006) Integration of urban and rural water supply for rural water supply. China Water Conservancy (1):50-52(in Chinese)

3. Yan GY, Xu J (2013) A preliminary study on the future development strategy of rural water supply in China. China Rural Water and Hydropower(4): 1-4(in Chinese)

4. Shi YZ, Zhang XM, Shi HX, Yan JZ, Hong DL (2017) Analysis of rural water supply management mode in Yunnan Province. China Rural Water and Hydropower (5):211-214(in Chinese)

5. Hu M, Yan XM, Li XQ, Song WK, Dong CJ (2015) Analysis of the characteristics and situation of rural water supply in China and suggestions for countermeasures. China Water Resources (11): 3-5(in Chinese) 